This is the author's final, peer-reviewed manuscript as accepted for publication. The publisher-formatted version may be available through the publisher's web site or your institution's library.

\title{
Students' expectations and motivation for service-learning in public relations
}

Nancy Muturi, Soontae An, and Samuel Mwangi

\section{How to cite this manuscript}

If you make reference to this version of the manuscript, use the following information:

Muturi, N., An, S., \& Mwangi, S. (2013). Students' expectations and motivation for service-learning in public relations. Retrieved from http://krex.ksu.edu

\section{Published Version Information}

Citation: Muturi, N., An, S., \& Mwangi, S. (2013). Students' expectations and motivation for service-learning in public relations. Journalism \& Mass Communication Educator, 68(4), 387-408.

Copyright: (C) AEJMC 2013

Digital Object Identifier (DOI): doi:10.1177/1077695813506992

Publisher's Link: http://jmc.sagepub.com/content/68/4/387

This item was retrieved from the K-State Research Exchange (K-REx), the institutional repository of Kansas State University. K-REx is available at http://krex.ksu.edu 


\title{
Students’ Expectations and Motivation for Service-Learning in Public Relations
}

\author{
Nancy Muturi, Soontae An, and Samuel Mwangi
}

\begin{abstract}
This study is based on a survey of public relations students and examines their attitudes, expectations, and motivations for participating in curriculum-infused service-learning projects. Results indicate that prior participation does not influence attitudes or expectations, but motivation to participate in the project was significantly associated with positive attitude and higher expectations. Students' expectations, which include social and professional growth, and psychological and altruistic gratification through community contributions, indicate a need for discipline-focused service-learning programs and for a focus on civic engagement given the role of public relations in relationship building and in strategically addressing social issues that impact society.
\end{abstract}

Keywords - Service-learning, public relations, motivation, attitudes, expectations

Maybe cited as follows:

Muturi, Nancy, An, Soontae, \& Mwangi, Samuel (2013). Students' Expectations and Motivation for Service-Learning in Public Relations, Journalism and Mass

Communication Educator, 68(4) 387 - 408.

Publication date: December, 2013 


\section{Students' Expectations and Motivation for Service-Learning in Public Relations}

“Tell me and I forget, teach me and I may remember, involve me and I learn.”

- Benjamin Franklin

Service-learning is an evolving pedagogical approach that provides students with an opportunity to make a difference in the civic life of communities while developing a combination of knowledge, skills, values and motivation to make that difference. ${ }^{1}$ It is a form of teaching that involves students’ performing community service in order to gain knowledge and skills connected to curricular objectives. ${ }^{2}$ This style of active learning promotes understanding and context for the students while helping spark knowledge of their own lives and the world outside the classroom. ${ }^{3}$

The service-learning approach, now widely accepted as a form of experiential education, incorporates students' involvement into the dynamics of experiential learning and the rigors and structure of an academic curriculum. ${ }^{4}$ Unlike other pedagogical approaches that are less engaging or volunteer programs where students opt to participate, service-learning is incorporated into the curriculum. It enables students to apply course theory by working on a project for an agency, most often a nonprofit community organization, ${ }^{5}$ which Worley $^{6}$ refers to as true service. Servicelearning has been associated with boosting students’ critical thinking skills, improving integration of theory and practice, and helping them clarify career goals and develop skills to succeed in the workplace, including team-building and interpersonal skills. ${ }^{7}$ Other benefits include serving as a positive influence in civic responsibility and life skills, ${ }^{8}$ personal and interpersonal development, social responsibility, improvements in academic learning, ${ }^{9}$ development of closer relationships among students,10 and increased job satisfaction as a result of this real-life experience. ${ }^{11}$ The 
Association of American Colleges and Universities praises service-learning as one of the promising "high-impact" activities that engages students and thereby improves their learning. ${ }^{12}$

This past decade, more educators have recognized the value of service-learning in the mass communications discipline, particularly in public relations coursework ${ }^{13}$ and the overall curriculum. ${ }^{14}$ Indeed, Lubbers and Gorcyca ${ }^{15}$ acknowledge that, because of the didactic nature of prerequisites, which include introductory, writing, planning and other skills development courses, upper-level offerings should foster "active learning” or collaborative strategies. It is quite evident that service-learning pedagogy lends itself well to the discipline; although much of student involvement has traditionally been geared toward pre-employment skills through internships, volunteer activities, practica, work for a campus publication and other forms of experiential learning with the goal of building portfolios. ${ }^{16}$

In spite of this acknowledgement and the valuable asset to the public relations curriculum, specifically on projects that focus on students and community partnerships, studies have noted that pedagogical research is still lacking. ${ }^{17}$ A 2011 special issue of Public Relations Review focused on public relations pedagogy with few studies on students' experiences and outcomes in service-learning. ${ }^{18}$ Overall, however, there has been minimal published research that investigates students' perceptions of their service-learning experience. ${ }^{19}$ Researchers also have highlighted the limited empirical studies on the impact of the service-learning approach to teaching or systematic assessment of learner outcomes ${ }^{20}$ beyond the existing anecdotal reports of benefits, which is descriptive in nature ${ }^{21}$, or a consistent development of tools to assess them. ${ }^{22}$ Even scarcer is the understanding of the level of students' motivation to engage in service-learning programs that are integrated in the public relations curriculum requiring students to participate in civic engagement as opposed to doing so on a voluntary basis. The fundamental question to ask of any educational program or intervention is how students are affected since any understanding on the effect it has 
on educational and personal development has implications not only for the students, but also for long-term institutional policy. ${ }^{23}$

The current study focuses on students enrolled in the public relations campaigns, a capstone course that, by default, uses the service-learning approach and seeks to understand students' motivation to engage in the predetermined class projects. Such projects mostly involve nonprofit agencies that deal with critical social issues within surrounding communities. Extant literature addresses students' motivation to engage in volunteer activities. However, little is known about their motivation and expectations in predetermined programs that require them to engage and how this affects their attitudes toward service-learning and overall contributions to the community programs in which they engage. It is important to examine students' motivation and expectations in such projects and how that relates to their attitudes toward service-learning and overall contributions to the community programs in which they engage. The current study also examines if students' prior engagement in other service-learning projects within and outside the public relations curriculum, including volunteering, determines their motivation and attitudes toward participation in the capstone service-learning course.

\section{Critical Foundations of Service-learning}

The philosophical writings of John Dewey and Paulo Freire provide a foundation for service-learning research and pedagogy. Dewey, a towering American intellectual of his time, often is seen as the founding father of the philosophy of service-learning in education. ${ }^{24}$ He viewed education as the process of learning from experience that was accompanied by reflective activity and ultimately promoted good citizenship, community well-being and democracy. Dewey argued that learning must involve identifying problems and trying to solve them in real life, where real knowledge comes only through the experience of learning that occurs within a meaningful context. To him, learning occurs when the student constructs meaning from the 
interaction of knowledge and the experience; therefore, educational institutions should be equipped to give students an opportunity for acquiring and testing ideas and information in active pursuit typifying social situations. ${ }^{25}$ Dewey further argued that education is a social process that fosters civic participation, communal living and democracy, emphasizing the "great waste" in education was that learning was not connected to the surrounding community.

A second scholarly underpinning to service-learning can be found in the work of Paulo Freire, a Brazilian educator who believed that education should help transform individuals into agents of change in their communities and that education must be accompanied by reflection and action. ${ }^{26}$ In his theory of participatory education, Freire emphasized that education must take place in collaborative settings that are community-oriented and must foster a critical spirit and civic engagement. ${ }^{27}$ In service-learning, the participatory approach provides opportunities for improved relationships and horizontal ties between academic institutions and community organizations, fostering the "social networks, educational, and economic opportunities and cultural richness" $(254)^{28}$ that is central to social and economic growth, and contributes to healthy communities that serve youth. Engaged communities, on the other hand, possess strong socioeconomic and service infrastructure and are rich in social capital. ${ }^{29}$

As a tool for community development through partnerships, service-learning provides students the opportunity to participate in programs that address social and environmental problems, to build stronger neighborhoods and communities, and to create more active and involved citizens, while "reinvigorating traditional classrooms" $(251) .{ }^{30}$ For instance, in their assessment of the service-learning impact, Astin and Sax found that "performing service for a political organization was positively associated with increased understanding of national problems, commitment to influencing the political structure, plans to work for a nonprofit agency, and increases in leadership ability” (261). ${ }^{31}$ This involvement of young adults makes them 
engaged citizens while providing them with opportunities to do good for others in their communities, preparing them for adulthood by sensitizing them to community needs and showing them how their time and talents can make a difference in their community. ${ }^{32}$

\section{Service-Learning and Civic Engagement}

Service-learning historically has been referred to as — and viewed synonymously as — social reconstruction, advocacy, and activism. ${ }^{33}$ Although still experimental in many institutions, the approach has increasingly been implemented across disciplines, most commonly in education and leadership studies, ${ }^{34}$ sociology, ${ }^{35}$ medicine ${ }^{36}$ and other health care-related fields that provide students an opportunity to practice what their disciplines have taught them within community settings where their work benefits others. ${ }^{37}$ Key emphasis is on the benefits to students and in building stronger connections between institutions, individuals, businesses, and formal and informal organizations in a community. ${ }^{38}$

Although not synonymous, service-learning is a component of civic engagement, defined as "working to make a difference in the civic life of communities and developing the combination of knowledge, skills, values and motivation to make that difference,” that encompasses actions people take individually or collectively to address issues of public concern (preface, iv). ${ }^{39}$ To a great extent, service-learning is viewed as a means to better citizenship and a greater understanding of community needs and also exposes students to the problems facing their communities and encourages their involvement in finding solutions. ${ }^{40}$ Students engage in activities that address human and community needs together with structured opportunities designed to promote student learning and development. ${ }^{41}$ Studies have noted this formalized approach enables students to learn and develop a thoughtfully organized service that is (a) conducted in and meets the needs of a community and is coordinated with an institution of higher education and with the community; (b) helps foster civic responsibility; (c) is integrated into and 
embraces the academic curriculum of the students enrolled; (d) and includes structured time for the students to reflect on the service experience. ${ }^{42}$

Service-learning is not particularly new in higher education, having been extolled by John Dewey, who, as early as 1902, stressed the value of a progressive education where thoughts and actions came together in classrooms and real-life settings. ${ }^{43}$ In public relations, it came into play in the 1970s when advertising and public relations became popular, which led to the introduction of upper-level and capstone courses into the curriculum. The approach received renewed interest in the 1990s driven by funding availability, institutional accountability and a genuine interest in service-learning, ${ }^{44}$ and an attempt to foster stronger relationships between institutions and communities around them.

Some examples of service-learning activities include providing service for local Girl Scout units, homeless shelters, visiting AIDS patients, tutoring children, producing community video or translating in legal clinics ${ }^{45}$ or working with university divisions such as disability or student services ${ }^{46}$ for practical experiences. Other students participate in international service and study-abroad programs, which is currently the focus of many academic institutions. This use of the service-learning approach is justifiable when it is tied directly to a special field of knowledge and is related to the professional activity within a discipline ${ }^{47}$ but also requires college-sponsored programs to be carefully thought-out and as rigorously evaluated as other academic programs.

Based on the renewed interest of service-learning in public relations, which has continued into the $21^{\text {st }}$ century, studies have attempted to address the limitations, specifically to provide a better understanding of the service-learning model for a capstone course. Over time, researchers have demonstrated support for service-learning assessment instrument ${ }^{48}$ and have documented the expectations and experiences of students and their supervisors in service-learning projects, specifically in internships. ${ }^{49} \mathrm{~A}$ recurring emphasis in extant literature is on the use of actual 
clients in undergraduate courses. ${ }^{50}$ In fact, the public relations field has an edge in providing leadership in service-learning based on the emphasis in improving relationships among individuals and between organizations and their publics, including community relations, in conceptual understanding, skill development, and integrating theory and practice. ${ }^{51}$

With the renewed interest, service-learning such as volunteerism has been encouraged and, to a great extent, incorporated into the university setting through its integration in classrooms and community projects. For example, in the aftermath of Hurricane Katrina in August 2005, Tulane University established a public service graduation requirement for undergraduate students. A survey of their views on this requirement reflected interest in community engagement, which also was a key reason for first-year students to choose the university. ${ }^{52}$ It is predicted that servicelearning initiatives will continue to increase as university service missions are "recast with a new vision for community outreach that matches the expertise and values of the university with the needs of local, state, national, and international communities”(113). ${ }^{53}$

In spite of current student engagement efforts, studies have indicated the need for a much more robust approach in which students do more than "some" good, but actually contribute to solving community problems ${ }^{54}$ or where service is something more than "do goodism." ${ }^{55}$ This level of involvement requires college-sponsored programs to be carefully thought-out and as rigorously evaluated as other academic programs. Additionally, it would require incorporating service-learning into the curriculum across disciplines. ${ }^{56}$ Skeptics, however, worry this approach would divert the basic mission of academic institutions with some scholars referring to students’ participation as "fluffy, feel-good stuff" with no scientific research that says this has made a difference in a student's education (411). ${ }^{57}$ This skepticism may be attributed to the limited knowledge on the effect of student participation in service-learning projects at individual and organizational levels. 
Faculty members who embrace service-learning value the meaning and purpose of this engagement, but they encounter challenges such as increased time commitment, varying student skill level and how to evaluate students' work. Other challenges include faculty reward systems that give more weight to traditional pedagogy and scholarship when it comes to retention, tenure and promotion and fail to acknowledge the value of service-learning. ${ }^{58}$ Despite these challenges, scholars have continued to argue that service-learning is a perfect fit for public relations because it offers students the opportunity to learn how to meet the needs of a client or their community and therefore benefits the students, their instructor, the community and the university.

\section{Motivation for Civic Engagement}

Volunteerism and community service by college students recently have received increased attention. What motivates students to participate in service-learning programs voluntarily has been attributed to egoistic motivation, altruistic and social obligation factors. ${ }^{59}$ Maslow's hierarchy of human needs emphasizes egoism where people are motivated by unmet needs that involve psychological well-being, safety and security, love and belonging, self-esteem and selfactualization. ${ }^{60}$ From this perspective, Winniford and colleagues contend that civic engagement through volunteerism is not just a way to serve society as an end in itself (altruistic motivation) but is a means for nurturing self-actualized human beings. Furthermore, Maslow's theory

reinforces the egoistic aspect of volunteer work in that people are motivated by unmet needs. ${ }^{61} \mathrm{~A}$ study asking why students participated in volunteer activities reported the most common reasons for engagement were: to help other people (91\%); to feel personal satisfaction (67\%); and to improve society as a whole $(61 \%) .{ }^{62}$

Expectancy motivation theory ${ }^{63}$ also is used to explain motivation for civic engagement. The theory suggests that behavior is caused by a belief that it will result in a desired reward or goal. Three factors affect behavior: (a) the need for achievement, which is defined as the capacity 
for taking pride in an accomplishment; (b) the need for affiliation, defined as the concern for one's relationship with others; and (c) the need for power, or wanting to have an influence or impact on others. ${ }^{64}$ These elements are relevant in explaining motivation for engagement and expectations from both voluntary service-learning programs and those embedded into the curriculum.

Prior participation in volunteer and service-learning projects is a key factor in determining students' attitudes, satisfaction and motivation to participate in curriculum-based projects. Astin and Sax reported that students’ prior participation in non-collegiate, volunteer programs was a predictor of satisfaction in collegiate service-learning opportunities and satisfaction with collegiate opportunities for leadership development. ${ }^{65}$ The current study examined the extent to which students’ prior participation in service-learning projects was associated with their motivation to engage in the project. Motivation also was measured in association with their attitudes toward the service-learning projects and what they expected to gain from their participation. This understanding is necessary for faculty and program administrators to develop effective service programs ${ }^{66}$ and in determining how best to incorporate service-learning into public relations curriculum to benefit students through personal and educational development, while enhancing community and institutional collaboration.

\section{Research Question and Hypothesis}

Based on the reviewed literature and theoretical foundations, the study is guided by the following research question and hypothesis:

RQ1: How do students understand the concept of service-learning?

H1: Prior participation in service-learning will be positively associated with students' attitudes toward the project. 
H2: Prior participation in service-learning will be positively associated with the expectations toward the project.

H3: Students' motivation will be positively associated with attitudes toward the servicelearning project.

H4: Students' motivations will be positively associated with expectations toward the service-learning project.

\section{Method}

Data presented in this study were gathered through a self-administered survey over five semesters in a Midwestern university. It is based on a purposive sample $(\mathrm{N}=96)$ of all students enrolled in public relations campaigns, a capstone course offered at the end of the curriculum and the only one that requires application of service-learning by virtue of working with real clients in designing communication programs. As Richards and Morse explains, a purposeful sample is used to enhance confidence that findings would reflect the phenomena of interest. ${ }^{67}$

As opposed to volunteering or internships, the predetermined service-learning projects are determined by instructors who work collaboratively with the clients to determine students' level and nature of involvement. These projects involve working directly with clients on various steps of campaign design and implementation with a goal of applying their learned skills and gaining real-world experience. Existing studies that address learner outcomes have focused on participants at the end of engagement projects ${ }^{68}$ or at the last week of the semester ${ }^{69}$ including their experiences in internships. ${ }^{70}$ The current study targeted students before engaging in the service-learning project and at the beginning of each class and, therefore, presents pretest results.

The survey instrument used was designed by Cohen and Kinsey ${ }^{71}$ but adapted from Aldoory and Wringley ${ }^{72}$, who used it to determine relative and absolute learning among public relations students. Thirteen items were adapted from that tool to measure key variables in this 
study: (1) level of motivation to engage in service-learning, (2) attitudes toward the servicelearning project; and (3) expectations from the participation in the project. A Likert scale was used in all 13 questions, with responses ranging from strongly disagree (1) to strongly agree (5). ${ }^{73}$ Motivation was measured by a single item: Relative to other assignments, I am motivated to work on a client's project $(M=4.3, S D=.76)$. Studies have previously used single-item measures of job-satisfaction ${ }^{74}$, effective college education ${ }^{75}$, clinical psychology and other disciplines ${ }^{76}$ and have confirmed the increased validity and flexibility. ${ }^{77}$ This is because single-items measures eliminate redundancy and a large number of items that appear similar, which leads to participant's fatigue, frustration and boredom. ${ }^{78}$

Attitude toward service-learning was measured by five items: 1) Relative to other assignments, the client's project is useful for placing classroom material in context $(M=4.38$, $\mathrm{SD}=.70)$; 2) Relative to other assignments, the client's project is an effective learning exercise ( $\mathrm{M}=4.5, \mathrm{SD}=.62)$; 3) Relative to other assignments, the client's project is helpful in understanding the relationship between the course and the real world $(\mathrm{M}=4.63, \mathrm{SD}=.55)$; 4) The client's project is helpful in understanding audiences and their roles in meaningful communication ( $\mathrm{M}=4.41$, $\mathrm{SD}=.70$ ); and 5) The client's project is helpful in understanding tactics and meaning of communication ( $\mathrm{M}=4.49, \mathrm{SD}=.58)$. The scale for attitudes toward the service-learning showed high reliability (cronbach alpha=.78) as the average of the five items.

Expectations from the service-learning project were measured using five items: 1) I believe I will learn how to be more tolerant of frustrating situations while dealing with a real client ( $\mathrm{M}=4.15, \mathrm{SD}=.88)$; 2) I believe I will learn how to manage my own time better ( $\mathrm{M}=3.8$, $\mathrm{SD}=.96)$; 3) I believe I will learn how to actually solve frustrating situations ( $\mathrm{M}=3.86, \mathrm{SD}=.82)$;

4) Working with a real client will help me learn to apply my skills in a real-life situation ( $\mathrm{M}=4.58, \mathrm{SD}=.59)$; and 5) Working with a real client will teach me how to compromise when 
easy solutions cannot be found $(\mathrm{M}=4.11, \mathrm{SD}=.72)$. The scale, average score of the five items, showed very high reliability (cronbach alpha=.83).

Additionally, five open-ended questions gathered data on their knowledge and understanding of service-learning (“What do you understand by the term service-learning?”); learning expectations (“What do you anticipate to learn from working with a real client?”), and their prior participation in service-learning projects ("Have you participated in a service-learning project before? If so, where?’). While considering the original research questions, respondents’ statements from the transcripts were read, categorized by color-coding and information arranged by recurring themes. ${ }^{79}$ With the inductive coding, data was inserted in the SPSS to derive simple frequencies from the open-ended questionnaire items. ${ }^{80}$ Prior participation was coded into "Yes" (1) and "No" (2) and additional details transcribed and analyzed alongside other responses from open-ended questions.

\section{Results}

A total of 96 students enrolled in public relations campaigns course participated in the study over five semesters. The distribution of students was as follows: Semester $1(\mathrm{~N}=19)$, Semester $2(\mathrm{~N}=18)$, Semester $3(\mathrm{~N}=23)$, Semester $4(\mathrm{~N}=20)$ and Semester $5(\mathrm{~N}=16)$. Each semester, the public relations campaigns class has a homogenous group of students, all of whom take the same pre-requisites for the capstone course. Groups have similar experiences in the public relations sequence in terms of courses taken with the exception of the capstone project, which varies by semester based on instructors’ interests and preference in terms of client selection. Service-learning projects are mainly implemented collaboratively with nonprofit organizations within the surrounding communities and each group working with a different organization. Students participated in campaigns such as: watershed management, ecosystems 
health, HIV/AIDS communication, gender equity advocacy, and a marketing campaign for local grocery stores in rural and neighbourhood communities.

Students' understanding of service-learning. The study's research question sought to gather information on students’ knowledge and understanding of the service-learning concept (RQ1). This understanding is a necessary component for meaningful engagement of all participants and could determine their expectations and/or attitudes toward participation in the project. In response to the open-ended question "What do you understand by the term servicelearning?” students provided a variety of responses that were grouped into (a) civic engagement, where they learn about communities and provide service to address issues affecting them (55\%), (b) as professional development, where they learn to apply public relations skills in real life (35\%), and (c) as volunteering (4\%). As shown in Table 1, which gives examples of students' statements, only a small number of students (4\%) did not know what service-learning means. This lack of knowledge may be attributed to the absence of a service-learning component in the public relations curriculum and students' lack of prior participation in this learning approach even in courses taken outside the discipline.

Prior engagement in service-learning. Prior engagement in volunteer non-collegiate activities has been shown to motivate students to participate in service-learning projects. ${ }^{81}$ In response to the question “Have you participated in a service-learning course before?” only $40 \%$ indicated having previously participated, as opposed to $60 \%$ of students who had not. Among those with prior participation, the most commonly mentioned opportunities were through leadership studies where service-learning is required in various courses. Some students mentioned internships, and a small number mentioned courses such as PR Techniques and Fundraising for Nonprofits, both of which occasionally use the service-learning approach, depending on faculty interests. (The latter is an elective that is not taught on a regular basis.) 
Table 1 here

Only a few students mentioned volunteer activities as part of service-learning, which implies that either there is limited volunteerism among public relations students during their college years or they were unaware whether it would count as service-learning. The number of students who reported prior participation in service-learning projects has not been consistent but declined over time. For instance, 11 students in the first semester $(\mathrm{N}=19)$, nine in semester 2 $(\mathrm{N}=18)$, eight in semester $3(\mathrm{~N}=23)$, and five in both semesters $3(\mathrm{~N}=20)$ and $5(\mathrm{~N}=16)$ had participated in service-learning prior to enrollment in the capstone course. The majority reported some prior experience through leadership studies, and one of them through an internship.

The first hypothesis predicted that students’ prior participation in service-learning will be associated with their attitudes toward the project. Results show no significant differences between two groups ( $t=-5.20, \mathrm{df}=93, \mathrm{p}=.604)$ - those who participated before $(M=4.51, S D=.46)$ vs. those who did not participate $(M=4.46, S D=.06)$. $\mathrm{H} 1$ was not supported. Irrespective of their prior engagement, students had a positive attitude toward the service-learning project with mean scores on the five items ranging from 4.38 to 4.63 on a scale of 1 (strongly disagree) to 5 strongly agree. One item “Relative to other assignments, a client’s project is helpful in understanding the relationship between the course and real world” scored the highest (M=4.63). This may be explained by students’ understanding of service-learning as a professional-development opportunity that will enable them to learn how to apply public relations skills while working with real clients as opposed to hypothetical situations.

Expectations toward service-learning. Students' expectations for engaging in servicelearning were measured with five items, and results show moderately high expectations with mean scores ranging from 3.8 to 4.58 on a scale of 1 (strongly disagree) to 5 (strongly agree). 
Two items — "I believe I will learn how to manage time better" (M=3.8 SD=.96) and "I believe I will learn how to actually solve frustrating situations” $(\mathrm{M}=3.86 \mathrm{SD}=.82)$ — produced the lowest scores or less than 4.0. For the second hypothesis, it was predicted that prior participation will be positively associated with the expectations toward the project. Results show no significant differences between two groups $(t=.238, \mathrm{df}=89, \mathrm{p}=.81)$ — those who partipated before $(\mathrm{M}=4.12$, $\mathrm{SD}=.55)$ vs. those who did not participate $(\mathrm{M}=4.09$, $\mathrm{SD}=.67)$. H2 was not supported.

In the open-ended question that asked "What do you anticipate learning from using a real client in this PR campaigns course?” three main themes emerged from their responses: gaining practical experience; profesional development through a better understanding of the PR process; and personal development through interaction with clients. For gaining practical skills, responses included: "having a great hands-on experience”; “learning what it would actually be like to work in an agency"; "getting a better idea of what PR is”; and "being able to implement techniques learned in class.” For professional development, examples of students’ responses included: "learning about working with budget and time constraints, realistic expectations and goal setting"; "account management”; "getting the direct opinion from client”; "getting positive/negative feedback"; "learning to think outside the box more and take the class more seriously"; "learning what it would actually be like to work in an agency"; and "learning more about nonprofit [PR] and how to complete a campaign from start to finish on their behalf.” For personal development, students' responses included: “working with the client and listening to their expectations”; “gaining better client/personal interaction skills”; “working with real people and how to actually develop tactics that will be used"; and "learning how to actually interact with a professional.”

Motivation toward service-learning. Irrespective of their prior engagement status, participants were relatively highly motivated to engage in the project. In response to the statement “Relative to other assignments, I am motivated to work on a client's project,” results showed 
relatively high motivation: strongly agree (47.9\%); agree (34.4\%); neutral (17.5\%); and no students disagreed with the statement. Since those who strongly agreed accounted for almost $50 \%$, we decided to see differences between them and the rest who answered otherwise. Those who answered "agree" and "neutral” were combined and compared with those who answered "strongly agree.” For further analysis, two groups were created - high motivation (strongly agree, 47.9\%) vs. lower motivation (all others, 52.1\%). This grouping was done because the motivation variable was quite skewed and using the motivation measure as the original five-point continous variable was not feasable.

For the third hypothesis, students' motivation was examined in association with attitudes toward the service-learning project. Results show a significant difference between high motivation and lower motivation ( $t=-5.34, d f=94, p=.001)$ : those with lower movitation $(M=4.27$, $S D=.43)$ vs. those with high motivation $(M=4.71, S D=.39)$. Correlations between attitudes and the original movitation values also showed a significant relationship. These findings provided support for H3, where students who are highly motivated showed more positive attitudes toward the service-learning project.

In testing the forth hypothesis that students' motivation will be positively associated with their expectations toward the project, results also show a significant difference between high motivation and lower motivation $(t=-3.704, \mathrm{df}=94, \mathrm{p}=.001)$ : those with lower motivation $(\mathrm{M}=3.89, \mathrm{SD}=.62)$ vs. those with high motivation $(\mathrm{M}=4.33, \mathrm{SD}=.54)$. Similarly, correlations between expectations and original motivation values also were significant except for one item ("I believe I will learn how to actually solve frustrating situations"). The findings provided support for $\mathrm{H} 3$, where students with high motivation showed higher expectation toward the servicelearning project compared with those with lower motivation.

\section{Discussion}


This study examined the motivation, attitudes and expectations among public relations students who engaged in predetermined service-learning projects that were incorporated in the curriculum as opposed to volunteerism or internships where students chose the project or agency to work with. As the expectancy motivation theory indicates, motivation is a necessary component in determining behaviors that are based on the belief that they will result in a desired reward or goal. Attitudes also tend to be associated not only with motivation but also with past experiences and expectancies. It is necessary to understand all three variables in designing effective service-learning projects with the desirable learning outcomes for all parties.

On their understanding of the service-learning concept (RQ1), results show that, although only a few (40\%) had previous experience in service-learning projects, mostly in other disciplines, students have a general understanding of the concept of civic engagement. This concept also may be viewed as an altruistic activity — " assisting the community to better the people’s lives in it” and "helping others” but also as a skill-development opportunity "learning what PR is all about” and “real-world experience/learning public relations.”

From a civic engagement perspective, students had an understanding that they would be involved in "real issues" that affect their communities while learning from agencies that address them. These findings echo previous arguments that participation is motivated by altruistic and social obligation factors $^{82}$ and by unmet needs of society, while fulfilling self-actualization human desire. $^{83}$ Students' responses about their understanding of service learning also indicate that students understood service-learning as a tool for community development where they address social issues that affect local communities, for example, HIV/AIDS. Students also understood service-learning as a part of civic engagement, for instance, "the need to be more informed" and “gaining more knowledge about community issues.” This role of public relations in civic 
engagement and community development is, however, not addressed adequately in previous studies, particularly where such issues are incorporated into the public relations curriculum. Service-learning is considered as "a form of experiential education in which students engage in activities that address human and community needs together with structured opportunities intentionally designed to promote student learning and development” (20) ${ }^{84}$ This implies a need for good working relationships between institutions and the communities they serve, giving students the opportunity for experiential learning. Results show that in spite of the acknowledged role of public relations in relationship-building between institutions and communities, there are few service-learning opportunities for public relations students. This may be explained by the limited number of mass communication courses that use the approach within the mainstream curriculum, which is demonstrated by the lower number of students who had participated in service-learning projects prior to the capstone course. This finding is in line with previous studies that address the didactic nature of public relations prerequisites for the capstone course $^{85}$ that do not provide an opportunity for service-learning until the final course in the public relations sequence. The critical role of service-learning in public relations has been a subject of pedagogical debate and writings, which has intensified in recent years. However, there is no systematic approach for adopting this method within the discipline besides individual instructor interests.

Although students have the opportunity to enroll in service-learning courses in other disciplines, most often in leadership studies, it is imperative to offer discipline-focused servicelearning opportunities ${ }^{86}$ in public relations courses to provide students with the expected hands-on and professional skills earlier in the education process rather than in their final year of college. Important to note, however, is that not all institutions offer leadership studies and not all students participate in or have interest in such studies, which leaves them with limited or no opportunities. 
The study also found a considerably positive attitude toward service-learning among students irrespective of their prior engagement in such projects with no significant difference between those who had participated and those who had not (H1). This implies that students would be receptive to incorporating the service-learning approach at any level within the public relations curriculum. Given the critical role service-learning plays in civic engagement and professional development among young adults, it is necessary to infuse it within the public relations discipline to ensure meaningful engagement.

Students’ prior participation in service-learning projects also was not significantly associated with their motivation to participate in the service-learning project (H2). This prior experience among some students did not influence, either positively or negatively, their motivation to engage in the service-learning project. This finding also could be attributed to the lower number of students who had prior participation (40\% vs. $60 \%$ who had not) and the fact that those who had prior participation had done so through other disciplines. As other studies have emphasized, service-learning enables students to apply course theory into practice through working on a real agency ${ }^{87}$, but it is more meaningful if it is tied directly to a special field of knowledge and related to the professional activity within a discipline ${ }^{88}$, in this case, public relations.

Motivation, on the other hand, had a significant association with attitudes toward engagement in the project (H3). Students with high motivation also had a positive attitude toward engaging in service-learning. While this may be said of all students with higher learning motivation, the significant difference between the two groups indicated a need for examining motivation as a crucial component for service-learning irrespective of whether they initiate the project or if it is embedded in the curriculum. A key motivating factor that students indicated in the open-ended questions was their desire to move away from hypothetical classroom situations 
and into real-world setting as the site for education. As Winniford and colleagues indicate, students' motivation may be associated with the need for achievement, affiliation or power to influence others ${ }^{89}$, all which could be attributed to a positive attitude toward any project that would meet these needs. It is necessary to understand the key factors and to reinforce them in a carefully thought-out service-learning public relations program and to evaluate how these elements are achieved from a student's perspective.

Expectations for service-learning varied with motivation, where those with high motivation also demonstrated higher expectations for engaging in the service-learning project regardless of their prior experiences (H4). As indicated in both qualitative and quantitative responses, their main expectations may be broken down into knowledge and skill-building (on theory and skills application), professional growth and development (developing and implementing a PR project; communicating and relating with other professionals), and personal development (dealing with frustrating situations, time management, independence and problemsolving skills). There also was the expectation among students to learn about the issue itself and how to address it by helping the communities. This finding is in line with other studies that describe service-learning as a opportunity for civic engagement by learning about community problems and finging solutions on how to address them. ${ }^{90}$ Like in other studies on servicelearning, ${ }^{91}$ many students found this was an opportunity to learn about the real world outside the classroom.

\section{Conclusion}

In conclusion, this study addressed students’ motivation for engaging in service-learning public relations projects that are embedded into the curriculum. It also examined their atittudes and expectations for the service-learning project in which they would be engaged. It highlights the fact that students' motivation to participate in predetermined service-learning projects is a key 
determining factor in their attitudes toward the project itself and the expectations from participating. While prior experience in service-learning is not associated with either motivation or attitudes toward their participation, it is important to understand the nature of prior engagement to determine whether it is discipline specific. Also critical is the understanding of key servicelearning concepts among all parties involved, particularly how they relate or apply to the public relations discipline.

The study underscores the role of public relations in civic engagement, specifically based on the focus in relationship-building and community relations. Given the current emphasis in relationships between academic institutions and communities and the need for them to work closely together as demonstrated by Tulane University in the aftermath of Hurricane Katrina, incorporating service-learning into the curriculum becomes a necessity. Promoting servicelearning as part of civic engagement also would ensure support from communities that seek partnerships with academic institutions in finding solutions to issues affecting them. Because students are a part of those communities, they should be equally engaged in systematically planned academic programs within their disciplines. Results from this study indicate positive attitudes toward service-learning and high motivation for engaging in the service-learning programs among public relations students. This also indicates service-learning needs to be performed much earlier in their academic careers. Stressing the benefits of the service-learning approach would only reinforce their expectations, which includes professional development while learning how to apply their public relations skills.

The findings in this and previous studies have several implications for the public relations field. First, there is a need for service-learning to be incorporated into more courses beyond the senior-level capstone courses. This would provide the opportunity for students to be engaged earlier in their academic career and learn from a variety of projects that provide a link between 
theory and practice. Second, the concept of service-learning in public relations needs to be clearly explained before starting the project. Though the majority of students had an understanding of the concept, their responses indicated a lack of consistency in this understanding of the concept or expectations. Additionally, it seemed as if students did not know what would constitute servicelearning beyond internships and other courses that are incorporated into the curriculum, which were limited in this particular case. Having a concrete understanding of the term would provide clear expectations from not only students, but also faculty and the community collaborator. This also would make the process a lot smoother and enable better evaluation of the program.

Third, it is necessary to speak of service-learning within the wider civic engagement context. This also would require defining these terms and demonstrating how they fit into the public relations discipline. Though students indicated understanding "service-learning” as helping communities, their participation was viewed as just “doing good” for the surrounding communities. This contribution is not viewed within the wider "civic engagement" context beyond applying skills. It is unclear from their responses how their engagement contributed toward building better citizenship beyond their immediate contribution to the project. Emphasizing long-term benefits to all parties involved — students, faculty, communities and the university institution — and in building stronger relationships with communities they serve as individuals or as an institution is necessary in understanding their contributions and role in civic engagement.

A long-term study is necessary to determine how such service-learning projects contribute to the overall change in attitudes, intentions and future engagement or sharing best practices and lessons learned by former students to enhance this understanding. Furthermore, a more detailed analysis is needed in assessing service-learning motivations, expectancies and outcomes at various stages as a step toward development of a model that institutions and mass 
communications programs could apply should they consider incorporating service-learning into their public relations curriculum.

\section{Limitations}

Limitations of the study, which includes a small purposive sample $(\mathrm{N}=96)$ gathered over five consecutive semesters, need to be highlighted. Although the entire population of public relations students within the specific insitution was targeted, we acknowledge that findings from the study cannot be generalized to other institutions or public relations programs. This small sample may be attributed to the accreditions policies that require small classes, particularly as students enrolled in the skill-oriented prerequisites including writing and production courses. A solution to this limitation would be to expand the study to similar institutions that offer the public relations curriculum and have a service-learning component.

In addition to the sample size, the time frame for data collection was a key limitation based on the fact that students' views, perceptions and interests change over time regardless of courses taken. The institutional emphasis on service-learning (or lack thereof) or other aspects of community service and how students are rewarded for their participation also would influence how they percieve it and the extent to which they engage in it throughout their academic career. The current study did not assess those external influences or the institutional culture but recommend it in future studies that seek to create a better understanding of the effect of servicelearning in creating better citizenship.

The fact that data collection started at the beginning of the project to determine students' attitudes, motivation and expectations and no systematic evaluation conducted to determine any change in those three aspects was another key limitation of this study. It is possible that their attitudes and expectations could change in the course of the service-learning project based on positive or negative experiences, interaction with clients and working in teams, among other 
factors. It also is possible that there were differences in students perceptions of the project as the semester progressed. These individual differences or the changes in their motivation, attitudes and expectations were not examined, which is acknowledged as a limitation in the current study. For future studies, we recommend a systematic experimental study with a matched sample in pretest and post-test to effectively assess the effect of service-learning (or lack thereof) in public relations and other mass communications programs. 
Table 1: Understanding Service-Learning

\begin{tabular}{|c|c|c|}
\hline Themes & Percentage & Examples of students responses \\
\hline $\begin{array}{l}\text { Civic } \\
\text { Engagement }\end{array}$ & $\begin{array}{c}55 \% \\
(\mathrm{~N}=53)\end{array}$ & $\begin{array}{l}\text { - Learning how to work in a real community [while] helping others } \\
\text { - Helping out the community while learning how to do so for the better in the future } \\
\text { - Learning about the community (e.g., demographics, beliefs, etc.), so you can better help and inform } \\
\text { - } \text { them about your cause } \\
\text { - Learning through helping other people in the community } \\
\text { - I learn about community service and how to benefit/give back to the community I live in. } \\
\text { - I hope to become more informed on HIV/AIDS. } \\
\text { - We are not only doing the community a favor by participating. Doing this project will increase my } \\
\text { knowledge in both in PR field and about AIDS } \\
\text { Learning from others within your community and finding ways to best serve them depending on } \\
\text { their needs }\end{array}$ \\
\hline $\begin{array}{l}\text { Applying PR } \\
\text { Skills }\end{array}$ & $\begin{array}{c}37 \% \\
(\mathrm{~N}=35)\end{array}$ & $\begin{array}{l}\text { - } \text { A type of education based on real-life application } \\
\text { - Using real-life situations for learning your field - Hands on } \\
\text { - Learning how to effectively master PR skills by also serving community organizations. } \\
\text { - } \quad \text { Learning through experience - by working in the community hands on, by working on actual } \\
\text { - } \quad \text { Leampaigns } \\
\text { - Learning tactics and elements on how to apply them to help communities } \\
\text { - } \quad \text { Real-world experience/learning public relations }\end{array}$ \\
\hline Volunteerism & $\begin{array}{c}4 \% \\
(\mathrm{~N}=4)\end{array}$ & $\begin{array}{l}\text { - Volunteering learning through community service } \\
\text { - I perceive it as volunteering in some sort of community, sometimes in a community/circumstance } \\
\text { unfamiliar to the volunteer, followed by reflection to reach understanding of the experience to serve } \\
\text { the community } \\
\text { - You are learning by volunteering your time/resources to a local organization to help them }\end{array}$ \\
\hline Don’t know & $\begin{array}{c}4 \% \\
(\mathrm{~N}=4)\end{array}$ & $\begin{array}{l}\text { - I don’t know what it means and frankly I think it is a made-up term } \\
\text { - I don’t know } \\
\text { - No idea } \\
\text { - Not a lot, other than what it literally means - learning from community work. }\end{array}$ \\
\hline
\end{tabular}




\title{
Endnotes
}

\begin{abstract}
${ }^{1}$ Thomas Ehrlich, "Civic responsibility and higher education (Phoenix: Oryx Press, 2000); K. M. Quintanilla and S. T. Wahl. Incorporating service-learning into communication courses: Benefits, guidelines, and challenges. Texas Speech Communication Journal, 30 (1, 2005): 67-71.

2 Shelley H. Billig. "Support for K-12 service-learning practice: A brief review of the research." Educational Horizons, 80 (2002): 184-189.

${ }^{3}$ Linda Aldoory and Brenda Wrigley, "Exploring the use of real clients in PR campaigns course," Journalism and Mass Communication Educator, 54 (2000): 47-58; Robert Bringle, and Julie Hatcher, "Campus-Community Partnerships: The Terms of Engagement." Journal of Social Issues, 58(January 2002): 503-516.
\end{abstract}

${ }^{4}$ Linda A. Mooney and Bob Edwards, "Experiential learning in sociology: service-learning and other community based learning initiatives," Teaching Sociology, 29, (April 2001). 181-194.

5 Ann H. Shiarella, Anne Mccarthy, and Mary L. Tucker, "Development and Construct Validity of Scores on the Community Service Attitudes Scale.” Educational and Psychological Measurement, 60 (2, 2000): 286-300; Money and Edwards. "Experiential learning in sociology: service-learning and other community based learning initiatives."

${ }^{6}$ Paul Worley, "Relationships: A new way to analyse community based medical education?" Education for Health, 15 (2, 2002): $117-12$

${ }^{7}$ Maryann J. Gray, Elizabeth H. Ondaatie, Ronald Fricker Jr. and Sandy A. Geschwind, "Assessing servicelearning: Results from a survey of "Learn and Serve America, Higher Education". Change: The Magazine of Higher Learning, 32 (2, 2000), 30-39; Kelly Werder and Karen Strand, "Measuring student outcomes of service-learning $\mathrm{n}$ the public relations campaigns course," Public Relations Review, 37, (2, December 2011): 478484

${ }^{8}$ Gray et al., "Assessing service-learning: Results from a survey of "Learn and Serve America, Higher Education”.

${ }^{9}$ Janet Eyler, Dwight Giles, and Christine Stenson. At a glance: What we know about the effects of servicelearning on college students, faculty, institutions \& communities, 1993-2000 (3rd Ed.) (Nashville, Vanderbilt University, 2001)

${ }^{10}$ Dwight E. Giles, Jr. and Janet Eyler, "The theoretical roots of service-learning in John Dewey: Toward a theory of service-learning." Michigan Journal of Community Learning, 11, (1994):77-85.

${ }^{11}$ Emma L. Daugherty, "The public relations internship experience: A comparison of student and site supervisor perspectives," Public Relations Review, 37(2011): 470-477

12 Association of American Colleges and Universities, "College learning for the new global century: A report from the National Leadership Council for Liberal Education and America's Promise", (Washington, DC: AACU, 2007)

${ }^{13}$ Daniel Panici and Kathryn Lasky, "Service Learning's Foothold in Communication Scholarship." Journalism and Mass Communication Educator, 57, (2, 2002): 113-25.

${ }^{14}$ Werder and Strand, "Measuring student outcomes of service-learning $\mathrm{n}$ the public relations campaigns course," Jeanette W. Drake. "Uniting service-learning and PR at the University of Findlay," Public Relations Tactics, 7 (9, 2000): 24-25; Suzannah A. Patterson. "How service-learning enhances your PR program," Public Relations Tactics, 11 (4, 2004): 23; Diane F. Witmer, Deborah A. Silverman, and Dennis J. Gaschen, "Working to learn and learning to work: A profile of service-learning courses in university public relations programs," Public Relations Review, 35, (2009): 153-155 
${ }^{15}$ Charles A. Lubbers and Diane Gorcyca, "Using active learning in public relations instructions: Demographic predictors of faculty use," Public Relations Review, 23(Spring 1997): 67-80

${ }^{16}$ Katherine N. Kinnick, "The communication campaign course as a model for incorporating service-learning into the curriculum," In D. Droge and B. O. Murphy (Eds.). Voices of strong democracy: concepts and models for service-learning in communication studies. (pp. 155-164), (Washington, DC: American Association for Higher Education Stylus Publishing 1999).

${ }_{17}$ Vicki Todd, and Jerry C. Hudson. "A content analysis of public relations pedagogical research articles from 1998 to 2008: Has PR research regarding pedagogy become less sparse," Southwestern Mass Communication Journal, 25 (1, 2009): 43-51; Charles A. Lubbers, "An assessment of predictors of student peer evaluations of team work in the capstone campaigns course." Public Relations Review, 37(5, December 2011).

18 Werder and Strand, "Measuring student outcomes of service-learning $\mathrm{n}$ the public relations campaigns course,"; Daugherty, "The public relations internship experience"; Todd and Hudson. "A content analysis of public relations pedagogical research articles from 1998 to 2008

${ }^{19}$ Julia Corbett and April Kendell, "Evaluating service-learning in the communication discipline", Journalism Educator, 53 (4, Winter 1999): 66-76

${ }^{20}$ Susan R. Jones and Kathleen E. Hill, "Understanding patterns of commitment: Student motivation for community service involvement," The Journal of Higher Education 74 (5, 2003): 516-539; Werder and Strand, "Measuring student outcomes of service-learning $n$ the public relations campaigns course" Aldoory and Wrigley, "Exploring the use of real clients in PR campaigns course,"; Mark Toncar, Jane Reid, David Burns, Cynthia Anderson and Hieu Nguyen, "Uniform assessment of the benefits of service learning: The development, evaluation, and implementation of the SELEB scale," Journal of Marketing Theory and Practice, 14 (3, March 2006): 223-238.

${ }^{21}$ Maureen S. Burrows, Sheila, Chauvin, Cathy J. Lazarus and Peggy Chehardy, "Required service-learning for Medical Students: Program Description and Student Response" Teaching \& Learning in Medicine, 11(4, 1999): 223-231; Daugherty, "The public relations internship experience: A comparison of student and site supervisor perspectives,"

22 Werder and Strand, "Measuring student outcomes of service-learning $\mathrm{n}$ the public relations campaigns course"; Corbett and Kendell, "Evaluating service-learning in the communication discipline."

23 Alexander W. Astin and Linda J. Sax, "How undergraduates are affected by service participation", Journal of College Student Development, 39 (May/June 1998): 251-262

${ }^{24}$ Giles and Eyler, "The theoretical roots of service-learning in John Dewey: Toward a theory of servicelearning."; Julie A. Hatcher, "The Moral Dimensions of John Dewey's Philosophy: Implications for Undergraduate Education." Michigan Journal of Community service-learning 4, (1, 1998): 22-29; Barbara Jacoby and Associates (Eds.). "Service-learning in Higher Education: Concepts and Practices," (San Francisco: Jossey-Bass, 1999); John A. Saltmarsh, "Education for critical citizenship: John Dewey's contribution to the pedagogy of servicelearning”, Michigan Journal of Service Learning, 3 (1,1996): 13-21

${ }_{25}$ Dewey, 1938) John Dewey, Experience and education, New York: Collier Books (1938); John Dewey, "The school and society," (Carbondale, Southern Illinois University Press, 1980)

${ }^{26}$ Freire, "Pedagogy of the oppressed", (New York: Continuum, 1970).

${ }_{27}$ Paulo Freire, Miguel Escobar, Alfred Fernandez and Gilberto Guevara-Niebla. Paulo Freire on higher Education: A Dialogue at the National University of Mexico, (Albany: State University of New York Press, 1994)

${ }^{28}$ Novella Z. Keith. "Can urban school reform and community development be joined? A potential of community schools," Education and Urban Society, 28(2, 1996): 237-268. 
${ }^{29}$ Marvis G. Sanders, Community involvement in schools from concept to practice. Education and Urban Society, 35, (2, 2003): 161-180.

${ }_{30}$ Alice Halsted, and Joan Schine, "Service-learning: The promise and the risk," New England Journal of Public Policy, 10 (1, 1994): 251-257.

31 Astin and Sax, "How undergraduates are affected by service participation"

32 Shiarella et al., "Development and Construct Validity of Scores on the Community Service Attitudes Scale"

33 Valerie McKay and Jeremy Estrella (2008). First-generation student success: The role of faculty interaction in service-learning courses. Communication Education, 57(3, 2008): 356-372.

34 Adrianna Kezar, “Assessing community service learning: Are we identifying the right outcomes?” About Campus, 7 (2, May-June, 2002): 14-20

35 Pierrette Hondagneu-Sotelo, and Sally Raskoff, "Community service-learning: Promises and Problems," Teaching Sociology, 22, (July 1994): 248-254.

${ }^{36}$ Burrows, et al. "Required service-learning for Medical Students: Program Description and Student Response"

${ }^{37}$ James L. Applegate, and Sherwyn P. Morreale. "Service-learning in communication: A natural partnership." In D. Droge and B. O. Murphy (Eds.). Voices of strong democracy: Concepts and models for service-learning in communication studies (pp. ix-xiv), (Washington, DC: American Association for Higher Education, 1999)

${ }^{38}$ Sanders, "Community involvement in schools from concept to practice."

${ }^{39}$ Ehrlich, "Civic responsibility and higher education"

${ }^{40}$ Ira Harkavy, and Daniel Romer, Service-learning as an integrated strategy. Liberal Education, 85.3 (Summer 1999): 14-20.

${ }^{41}$ Jacoby and Associates (Eds.). "Service-learning in Higher Education"; Witmer, et al., "Working to learn and learning to work"

42 Daniel Panici, and Kathryn Lasky, "Service Learning's Foothold in Communication Scholarship," Journalism and Mass Communication Educator, 57, (2, 2002): 113-25; Corbett and Kendell, "Evaluating service-learning in the communication discipline"

${ }^{43}$ Dewey, "Experience and education"

${ }^{44}$ Giles and Eyler, "The theoretical roots of service-learning in John Dewey"

45 Paul A. Soukup, Service-learning in communication: Why? In D. Dorge, B. Ortega Murphy (Eds.), Voices of strong democracy: Concepts and models for service-learning in communication studies, (pp. 7-12), (Washington, D. C.:

American Association for Higher Education, 1999).

${ }^{46}$ Mary L. Tucker, Anne M. McCarthy, John A. Hoxmeier, and Magarita M. Lenk. "Community servicelearning increases communication skills across the business curriculum," Business Communication Quarterly, 61(2, 1998): 88-99.

${ }^{47}$ Aldoory and Wrigley, "Exploring the use of real clients in PR campaigns course"

${ }^{48}$ Gray et al., "Assessing service-learning”

49 Daugherty, "The public relations internship experience: A comparison of student and site supervisor perspectives"

${ }^{50}$ Lynne M. Sallot, "Using a public relations course to build university relationships" Journalism and Mass Communication Educator, 51, (1996): 51-60; Rochelle L. Ford. "Activist teaching: Try public relations", International Journal of Media \& Cultural Politics, 1 (2, 2005): 221-225; Lolita Hendrix, "Give students a chance: Volunteer experiences often win-win situations," Public Relations Tactics, 10(3, 2003): 10; Aldoory and Wrigley, "Exploring the use of real clients in PR campaigns course"; Werder and Strand, "Measuring student 
outcomes of service-learning $\mathrm{n}$ the public relations campaigns course"; Witmer, et al. "Working to learn and learning to work"

${ }^{51}$ Laura K. Oster-Aaland, Timothy L. Sellnow, Paul Nelson, and Judy C. Pearson, "The status of servicelearning in departments of communication: A follow-up study." Communication Education, 53 (4, 2004): 348-356

${ }^{52}$ Barbara Moely, and Vincent Ilustre, “University students' views of a public service graduation requirement," Michigan Journal of Community Service Learning, 17(2, (2011): 43-58

53 Panici and Lasky, "Service Learning's Foothold in Communication Scholarship."

${ }^{54}$ Harkavy and Romer, "Service-learning as an integrated strategy."

${ }^{55}$ Panici and Lasky, "Service Learning's Foothold in Communication Scholarship."

${ }^{56}$ Burrows, et al., "Required service-learning for Medical Students: Program Description and Student Response"

${ }^{57}$ Gregory. B. Markus, Jeffery P. F. Howard, and David C. King, "Integrating community service and classroom instruction enhances learning: Results from an experiment." Educational Evaluation and Policy Analysis, 15 (4, 1993): 410-419.

${ }^{58}$ Chris Hammond. "Integrating Service and Academic Study: Faculty Motivation and Satisfaction in Michigan Higher Education," Michigan Journal of Community Service Learning, 1(1, 1994): 21-28; Kathleen M. Weigert. "Academic service learning: Its meaning and relevance," New Directions for Teaching and Learning, 78 (Spring 1998): 3-10

${ }^{59}$ Silvia Marotta, and Honey Nashman. "The Generation X College Student and their motivation for community service," College Student Affairs Journal, 17(2), 19-31.

${ }^{60}$ Janet C. Winniford, Stanley D. Carpenter, and Clint Grider, "Motivations of college student volunteers: A review," NASPA Journal, 34 (December, 1997): 134-146

${ }^{61}$ Winniford, et al, "Motivations of college student volunteer"

62 Astin and Sax, "How undergraduates are affected by service participation"

${ }^{63}$ David C. McClelland, John W. Atkinson, Russell A. Clark, and Edgar L. Lowell, "The achievement motive" (New York: Appleton-Century-Crofts 1953).

${ }^{64}$ Winniford, et al, "Motivations of college student volunteer"

${ }^{6}$ Astin and Sax, "How undergraduates are affected by service participation"

66 Winniford, et al, "Motivations of college student volunteer"

${ }^{67}$ Lyn Richards, and Janice M. Morse, "Readme first for a user's guide to qualitative methods" (2nd ed.), (Thousand Oaks, CA: Sage, 2007).

68 Aldoory and Wrigley, "Exploring the use of real clients in PR campaigns course"; Lubbers, "An assessment of predictors of student peer evaluations of team work in the capstone campaigns course."

${ }^{69}$ Werder and Strand, "Measuring student outcomes of service-learning $\mathrm{n}$ the public relations campaigns course,"

${ }^{70}$ Daugherty, "The public relations internship experience: A comparison of student and site supervisor perspectives"

${ }^{71}$ Jeremy Cohen, and Dennis F. Kinsey, "Doing good' and scholarship: A service-learning study", Journalism Educator, 48 (Winter 1994): 4-14

72 Aldoory and Wrigley, "Exploring the use of real clients in PR campaigns course"

73 Aldoory and Wrigley, "Exploring the use of real clients in PR campaigns course"

${ }^{74}$ Mark S. Nagy, "Using a single-item approach to measure facet job satisfaction," Journal of Occupational and Organizational Psychology, 75 (1, 2002):77-86.

${ }^{75}$ John P. Wanous, and Michael J. Hudy "Single item reliability: a replication and extension," Organizational Research Methods, 4 (October 2001): 361-375. 
76 Timo Christophersen, and Udo Konradt, "Reliability, validity, and sensitivity of a single-item measure of online store usability" International Journal of Human-Computer Studies, 69 (April 2011): 269-280

${ }^{77}$ Hyungil Kwon, and Galen Trail, The feasibility of single-item Measures in sport loyalty research. Sport Management Review, 8 (1, 2005): 69-89

${ }^{78}$ Christophersen and Konradt, "Reliability, validity, and sensitivity of a single-item measure of online store usability"

${ }^{79}$ Richard A. Krueger, and Mary A. Casey. Focus groups: A practical guide for applied research (3rd Ed.). (Thousand Oaks, CA: Sage, 2008).

80 Aldoory and Wrigley, "Exploring the use of real clients in PR campaigns course"

81 Astin and Sax, "How undergraduates are affected by service participation"

82 Silvia Marotta, and Honey Nashman. "The Generation X College Student and their motivation for community service,"

83 Winniford, et al, "Motivations of college student volunteer"

${ }^{84}$ Jacoby and Associates (Eds.). "Service-learning in Higher Education"

${ }^{85}$ Lubbers and Gorcyca, "Using active learning in public relations instructions"

86 Aldoory and Wrigley, "Exploring the use of real clients in PR campaigns course";

${ }^{87}$ Linda A. Mooney, and Bob Edwards, "Experiential learning in sociology: service-learning and other community based learning initiatives," Teaching Sociology, 29 (April 2001): 181-194; Shiarella, et al., "Development and Construct Validity of Scores on the Community Service Attitudes Scale"; Worley, "Relationships"

88 Aldoory and Wrigley, "Exploring the use of real clients in PR campaigns course"

89 Winniford, et al, "Motivations of college student volunteer"

${ }^{90}$ Quintanilla and Wahl. "Incorporating service-learning into communication courses"; Harkavy and Romer, "Service-learning as an integrated strategy."

91 Aldoory and Wrigley, "Exploring the use of real clients in PR campaigns course"; Bringle and Hatcher,

"Campus-Community Partnerships" 